\title{
Perbedaan Respon Seleksi, Kemajuan Seleksi, dan Jumlah Segregan Transgresif Hasil Persilangan Tomat Suka Naungan dengan Tomat Peka Naungan
}

\section{Different of Selection Response,Genetic Advance, and Number of Transgressive Segregants resulting of Crossed between Shade-loving Tomato $x$ Shade-sensitive Tomato}

\author{
Arya Widura Ritonga ${ }^{1}$, Muhamad Syukur ${ }^{1 *}$, Muhammad Achmad Chozin ${ }^{1}$, Awang Maharijaya ${ }^{1}$, Sobir $^{1}$ \\ ${ }^{1}$ Departemen Agronomi dan Hortikultura, Fakultas Pertanian Institut Pertanian Bogor \\ Jl. Meranti Kampus IPB Darmaga, Bogor, Indonesia \\ ${ }^{2}$ Pusat Kajian Hortikultura Tropika (PKHT) Institut Pertanian Bogor, Kampus IPB Baranangsiang \\ J1. Raya Pajajaran Bogor, Indonesia
}

Diterima 29 Januari 2019/Disetujui 22 Februari 2019

\begin{abstract}
Response selection and genetic advance informations are important genetic parameters for crop improvement program. SSH3 tomato genotype (shade-loving genotype), 4974 (shade-sensitive genotype), F2 and F3 population derived from "'SSH3 and 4974" were evaluated to estimate the transgressive segregant and the genetic advance on quantitative characters from crossed between shade-loving tomato with shade sensitive tomato at Pasir Kuda Station, Bogor Agriculture University, West Java, Indonesia from July 2016 until November 2017. The results showed that fruit set have high selection response (26.68\%) and genetic advance (22.99\%), fruit number and fruit weigth per plant had high selection response (68.81-71.36\%) and lower genetic advance (17.22-25.77\%), while fruit and vegetative characters had low selection (0-6.02\%) response and genetic advance $(0-2.22 \%)$. There were 10 transgressive segregants $(76.7 \%)$ resulted based on fruit set character, there were 3 transgressive segregants resulted based on fruit number an fruit weight per plant character, and there was not transgressive segregant resulted based on vegetative and fruit characters $(23.08 \%)$.
\end{abstract}

Keywords: differential selection, heritability, low light intensity.

\section{ABSTRAK}

Informasi tentang respon dan kemajuan seleksi merupakan informasi yang penting bagi kegiatan pemuliaan tanaman. Genotipe tomat SSH3 (suka naungan), 4979 (peka naungan), populasi F2 dan F3 hasil persilangan SSH3 dan 4979 dievaluasi untuk menduga segregan transgresif dan kemajuan seleksi beberapa karakter kuantitatif hasil persilangan tomat suka naungan dan tomat peka naungan di Kebun Percobaan IPB Pasir Kuda pada Juli tahun 2016 sampai dengan November 2017. Hasil pengamatan menunjukkan bahwa karakter fruit set menghasilkan nilai persentase respon seleksi (26.68\%) dan kemajuan seleksi (22.99\%) yang sama-sama tinggi, karakter jumlah buah dan bobot buah per tanaman tomat menghasilkan nilai persentase respon seleksi (68.81-71.36\%) yang tinggi dan kemajuan seleksi (17.22-25.77\%) yang lebih rendah,sedangkan karakter vegetatif dan karakter buah tomat menghasilkan persentase respon seleksi (0-6.02\%) dan kemajuan seleksi (0-2.22\%) yang sama-sama rendah. Terdapat 10 segregan transgresif (76.7\%) yang dihasilkan berdasarkan fruit set, 3 segregan transgresif $(23.08 \%)$ berdasarkan karakter jumlah dan buah per tanaman dan tidak dihasilkan segregan transgresif berdasarkan karakter vegetatif dan buah tomat.

Kata kunci: difrensial seleksi, heritabilitas, intensitas cahaya rendah.

\section{PENDAHULUAN}

Semakin berkurangnya lahan optimum untuk pertanian (Suwanda dan Noor 2014; Mulyani et al., 2016), kecilnya luas kepemilikan lahan pertanian oleh petani (BPS, 2013) dan penutupan awan (cloud cover) akibat perubahan iklim

* Penulis untuk korespondensi. e-mail: muhsyukur@ipb.ac.id yang tidak menentu merupakan beberapa tantangan pertanian di Indonesia saat ini. Sistem budidaya di bawah tegakan dengan penggunaan varietas tanaman toleran naungan yang berdaya hasil tinggi merupakan salah satu solusi yang dapat diandalkan untuk menghadapi tantangan-tantangan tersebut (Sulistyowati et al., 2016a).Tanaman tomat merupakan salah satu tanaman budidaya yang potensial dikembangkan sebagai varietas tanaman toleran naungan dan berdaya hasil tinggi (Bahrun, 2012; Baharudin et al., 2014; Sulistyowati et al., 2016a). 
Penelitian tentang mekanisme toleransi naungan dan pendugaan beberapa parameter genetik terkait toleransi naungan pada tanaman tomat sudah pernah dilakukan. Naungan paranet 50\% dapat menurunkan pecah buah (cracking) (Ilic et al., 2007), meningkatkan kekerasan buah (Ferre et al., 2009), serta menurunkan hasil sampai dengan 50\% (genotipe peka naungan) pada tanaman tomat (Baharuddin et al. 2014). Sulistyowati et al., (2016b) menjelaskan bahwa salah satu mekanisme toleransi naungan pada tanaman tomat adalah meningkatkan kandungan gula daun. Ritonga et al., (2018) melaporkan bahwa jumlah buah per tanaman dan bobot per buah memiliki pengaruh langsung yang kuat dan positif terhadap karakter hasil tomat pada naungan, sedangkan fruit set memiliki pengaruh tidak langsung yang tinggi dan kuat terhadap karakter hasil tomat di bawah naungan melalui jumlah buah per tanaman.

Informasi tentang seleksi kemajuan seleksi tanaman tomat toleran naungan yang berdaya hasil tinggi belum banyak ditemukan. Informasi ini penting untuk diketahui agar pemuliaan tanaman tomat toleran naungan yang berdaya hasil tinggi dapat lebih efektif dan efisien. Penelitian ini bertujuan untuk mengevaluasi respon seleksi, kemajuan seleksi dan segregan trangresif keturunan hasil persilangan tomat suka naungan dengan tomat peka naungan pada kondisi naungan paranet $50 \%$.

\section{BAHAN DAN METODE}

Penelitian ini terdiri atas 2 percobaan. Percobaan pertama dilaksanakan pada Juli - Oktober 2016 dan percobaan kedua dilaksanakan pada Agustus - November 2017. Percobaan pertama bertujuan untuk menseleksi segregan transgresif dan menduga respon seleksi tomat yang toleran naungan dan berdaya hasil tinggi, sedangkan percobaan kedua bertujuan untuk memverifikasi segregan transgresif hasil percobaan pertama dan menduga nilai kemajuan seleksinya.

\section{Percobaan Pertama}

Genotipe tomat SSH3 (suka naungan), 4979 (peka naungan) dan populasi F2 hasil persilangan SSH3 dan 4979 ditanam di Kebun Percobaan IPB, Pasir Kuda, Ciomas, Bogor pada percobaan pertama. Genotipe tomat suka naungan adalah genotipe tomat yang mampu menghasilkan produktivitas yang lebih tinggi pada kondisi naungan 50\% dibandingkan pada kondisi tanpa naungan. Genotipe tomat peka naungan merupakan genotipe tomat yang mengalami penurunan produktivitas lebih dari $50 \%$ pada kondisi naungan $50 \%$ dibandingkan pada kondisi tanpa naungan (Baharuddin et al. 2014).

Penanaman diawali dengan persemaian di dalam rumah plastik, menggunakan tray plastik dengan media semai tanah halus:arang sekam:pupuk kandang 1:1:1 sebanyak 1 benih per lubang tray dan disiram setiap hari. Pemupukan dilakukan 1 minggu sekali dengan menggunakan NPK 1616-16 konsentrasi $5 \mathrm{~g} \mathrm{~L}^{-1}$. Pengolahan lahan dan pemberian pupuk kandang dan kapur pertanian sebanyak 2 ton $\mathrm{ha}^{-1}$.
Pindah tanam tomat dilakukan pada 3 minggu setelah semai (MSS). Penanaman dilakukan pada bedengan berukuran $5 \mathrm{~m}$ x $1 \mathrm{~m}$ dengan jarak tanam $0.5 \mathrm{~m} \times 0.5 \mathrm{~m}$ di bawah naungan paranet plastik hitam 50\% dengan menggunakan rancangan augmented yang dimodifikasi. Genotipe tetua (SSH3 dan 4979) ditanam dalam 4 blok (ulangan) sebanyak 10 tanaman per blok, sementara populasi F2 sebanyak 220 tanaman ditanam menyebar pada ke empat blok (tanpa ulangan). Pemupukan dilakukan setiap minggu dengan pupuk NPK 16-16-16 dengan konsentrasi 5 - 15 $\mathrm{gL}^{-1}$ dan dosis $250 \mathrm{ml}$ per lubang tanam. Pengendalian hama dan penyakit dilakukan dengan pemberian insektisida 1-2 $\mathrm{ml} \mathrm{L} \mathrm{L}^{-1}$ serta fungisida dan bakterisida 1-2 $\mathrm{g} \mathrm{L}^{-1}$. Kegiatan pemeliharaan lainnya yang dilakukan adalah pengikatan, pewiwilan dan penyiangan.

Karakter yang diamati pada percobaan pertama terdiri atas tinggi tanaman $(\mathrm{cm})$, diameter batang $(\mathrm{mm})$, panjang internode $(\mathrm{cm})$, panjang buah $(\mathrm{mm})$, diameter buah $(\mathrm{mm})$, bobot per buah (g), fruit set (\%), jumlah buah per tanaman dan bobot buah per tanaman (g). Fruit set dihitung dengan membandingkan jumlah buah dengan jumlah bunga pada 4 -5 tandan bunga pertama. Selain pengamatan, juga dilakukan seleksi terhadap tanaman yang diduga sebagai segregagan transgresif. Kegiatan seleksi dilakukan dengan memilihi tanaman yang memiliki bobot buah per tanaman yang lebih baik dibandingkan kedua tetuanya.

Nilai heritabilitas arti luas, diferensial seleksi dan respon seleksi dihitung pada percobaan pertama. Nilai diferensial seleksi dihitung dengan rumus :

$$
G=\bar{X}_{s}-\bar{X}_{\mathbf{0}}
$$

keterangan :

$\mathrm{G}=$ diferensial seleksi,

$\bar{X}_{S} \cdot=$ nilai tengah populasi F2 setelah seleksi dan

$\bar{X}_{\mathbf{0}}=$ nilai tengah populasi $\mathrm{F} 2$.

Nilai respon seleksi dihitung dengan rumus :

$$
\mathrm{S}^{\prime}=\operatorname{Hbs} \times \mathrm{G},
$$

keterangan :

$\mathrm{S}^{\prime} \quad=$ respon seleksi

Hbs $(\%)=$ heritabilitas arti luas.

Nilai Hbs dihitung dengan rumus :

$\mathrm{Hbs}=\left(\sigma^{2} \mathrm{~g} / \sigma^{2} \mathrm{p}\right) \times 100 \%=\left(\left(\sigma^{2} \mathrm{P} 1+\sigma^{2} \mathrm{P} 2\right) / 2\right) / \sigma^{2} \mathrm{p} \times 100 \%$

keterangan :

$\sigma^{2} \mathrm{~g}=$ ragam genetik

$\sigma^{2} \mathrm{p}=\sigma^{2} \mathrm{~F} 2=$ ragam fenotipe,

$\sigma^{2} \mathrm{P} 1=$ ragam populasi genotipe $\mathrm{SSH} 3$

$\sigma^{2} \mathrm{P} 2=$ ragam populasi genotipe 4979 .

Kategori respon seleksi mengacu pada Rosyidah et al., (2016), yaitu rendah $\left(0<\mathrm{S}^{\prime}<3.3 \%\right)$, agak rendah $(3.3$ $\left.\leq \mathrm{S}^{\prime}<6.6 \%\right)$, cukup tinggi $\left(6.6 \leq \mathrm{S}^{\prime}<10 \%\right)$ dan tinggi $\left(10 \% \leq \mathrm{S}^{\prime}\right)$. 


\section{Percobaan Kedua}

Sebanyak 13 galur F3 (hasil seleksi populasi F2 pada percobaan 1), genotipe SSH3, genotipe 4979 dan populasi F2 hasil persilangan SSH3 x 4979 ditanam pada percobaan 2. Rancangan penanaman yang digunakan pada percobaan kedua yaitu rancangan augmented yang dimodifikasi. Genotipe tetua (SSH3 dan 4979) ditanam dalam 3 blok (ulangan) sebanyak 20 tanaman per blok, sementara 13 galur (setiap galur terdiri atas 20 tanaman) F3 dan 100 tanaman populasi F2 tanaman ditanam menyebar pada ke tiga blok (tanpa ulangan)Persemaian dan teknik budidaya pada percobaan 2 sama dengan pada percobaan 1 .

Verifikasi segregan transgresif pada percobaan kedua dilakukan dengan membandingkan nilai tengah dan ragam segregan dengan nilai tengah dan ragam tetuanya. Segregan yang memiliki nilai tengah karakter yang sama atau lebih baik dan ragam sama atau yang lebih kecil dibandingkan nilai tengah dan ragam salah satu tetuanya merupakan segregan yang terverifikasi sebagai segregan transgresif.

\section{HASIL DAN PEMBAHASAN}

\section{Kemajuan Seleksi}

Hasil pengamatan menunjukkan bahwa terdapat variasi persentase respon seleksi dan kemajuan seleksi pada berbagai karakter tomat di kondisi naungan. Persentase respon seleksi berkisar antara $0-71 \%$, sedangkan persentase kemajuan seleksi antara 0-22.99\% (Tabel 1 dan 2). Wulandari et al., (2016) juga melaporkan adanya variasi persentase respon seleksi, sementara Rosyidah et al., (2016) melaporkan adanya variasi persentase kemajuan seleksi antar berbagai karakter pada tanaman tomat tanpa naungan.
Karakter hasil tomat di bawah naungan memiliki persentase respon seleksidan kemajuan seleksi yang samasama tinggi. Sementara katakter vegetatif dan buah memiliki respon seleksi dan seleksi harapan yang rendah sampai cukup tinggi. Wulandari et al., (2016) dan Rosyidah et al., (2016) melaporkan bahwa persentase kamajuan seleksi harapan dan kemajan seleksi karakter hasil tanaman tomat seperti jumlah buah per tanaman, bobot buah per tanaman dan fruit set bervariasi dari rendah sampai tinggi. Variasi ini dipengaruhi oleh tetua genotipe yang digunakan dalam pembentukan populasi.

Karakter bobot buah per tanaman digunakan sebagai karakter seleksi pada seleksi pedigree populasi F2. Hal inilah yang menyebabkan tingginya nilai persentase respon seleksi karakter bobot buah per tanaman seperti yang dilaporkan oleh Yunandra et al., (2017). Sementara itu, nilai korelasi yang positif dan kuat antara karakter fruit set dan jumlah buah per tanaman dengan karakter bobot buah per tanaman tomat di bawah naungan (Ritonga et al., 2018) diduga merupakan faktor yang menyebabkan juga tingginya nilai persentase respon seleksi karakter fruit set dan jumlah buah per tanaman. Selain itu, salah satu faktor lainnya yang menyebabkan tingginya nilai persentase respon seleksi pada ketiga karakter tersebut adalah adanya keragaman genetik yang tinggi pada karakter bobot buah dan jumlah buah per tanaman pada populasi F2 yang digunakan. Hal ini diperlihatkan dari nilai Hbs yang tinggi pada kedua karakter tersebut (Tabel 1). Beberapa penelitian sebelumnya (WeselBeaver, 1992; Hanson et al., 2002; Wulandari et al., 2016; Rosyidah et al., 2016; Nilawati et al., 2017) melaporkan bahwa nilai heritabilitas arti luas karakter fruit set, jumlah dan bobot buah per tanaman tomat tanpa naungan bervariasi dari rendah sampai tinggi tergantung populasi yang digunakan. Nilai persentase respon seleksi dan kemajan seleksi yang

Tabel 1. Nilai tengah beberapa karakter tomat populasi F2 dan F2 terseleksi, diferensial seleksi dan dugaan kemajuan seleksi populasi $\mathrm{F} 3$ pada kondisi naungan paranet 50\%

\begin{tabular}{|c|c|c|c|c|c|c|c|c|}
\hline \multirow{2}{*}{ No } & \multicolumn{2}{|c|}{ Nilai tengah } & \multirow{2}{*}{ G } & \multirow{2}{*}{ Hbs (\%)* } & \multirow{2}{*}{$\mathrm{S}^{*}$} & \multirow{2}{*}{$\% \mathrm{~S}^{\prime *}$} & \multirow{2}{*}{ Kategori } & \multirow{2}{*}{ F3' } \\
\hline & $\mathrm{F} 2$ & $\mathrm{~F} 2^{\prime}$ & & & & & & \\
\hline $\mathrm{TT}$ & 94.14 & 101.09 & 6.95 & 86.73 & 6.02 & 6.40 & Cukup tinggi & 100.17 \\
\hline INT & 4.77 & 4.80 & 0.03 & 25.4 & 0.02 & 0.12 & Rendah & 4.79 \\
\hline DBAT & 7.50 & 7.76 & 0.26 & -11.68 & -0.03 & -0.40 & Rendah & 7.47 \\
\hline $\mathrm{PB}$ & 33.25 & 34.56 & 1.31 & 32.29 & 0.67 & 2.02 & Rendah & 33.92 \\
\hline DB & 33.85 & 34.93 & 1.08 & 58.69 & 0.68 & 2.01 & Rendah & 34.53 \\
\hline $\mathrm{BB}$ & 22.02 & 24.95 & 2.93 & 11.02 & 0.32 & 1.47 & Rendah & 22.34 \\
\hline FS & 48.24 & 66.92 & 18.67 & 68.92 & 12.87 & 26.68 & Tinggi & 61.11 \\
\hline JBT & 33.62 & 67.10 & 33.48 & 69.09 & 23.13 & 68.81 & Tinggi & 56.75 \\
\hline $\mathrm{BBT}$ & 758.38 & 1640.48 & 882.10 & 61.35 & 541.15 & 71.36 & Tinggi & 1299.52 \\
\hline
\end{tabular}

Keterangan : $\quad$ TT $=$ Tinggi tanaman $(\mathrm{cm}), \mathrm{INT}=$ Panjang internode $(\mathrm{cm}), \mathrm{DBAT}=$ Diameter batang $(\mathrm{mm}), \mathrm{PB}=$ Panjang buah $(\mathrm{cm}), \mathrm{DB}=$ Diameter buah, BB = Bobot per buah, FS = Fruit set $(\%), \mathrm{JBT}=$ Jumlah buah per tanaman, BBT = Bobot buah per tanaman (g), F2' = Populasi F2 hasil seleksi, G = Diferensial seleksi, Hbs = Heritabilitas arti luas, $\mathrm{S}^{\prime}=$ Dugaan kemajuan seleksi, F3' $=$ Dugaan nilai tengah populasi F3, *= jika bernilai negatif (-) maka dianggap nol (0) 
rendah pada beberapa karakter lainnya disebabkan oleh rendahnya keragaman genetik pada karakter-karakter tersebut pada populasi F2 yang digunakan. Sa'diyah et al.,
(2009) memaparkan bahwa besarnya efektivitas seleksi sangat dipengaruhi oleh besarnya keragaman dan nilai heritabilitas suatu karakter.

Tabel 2. Rata-rata beberapa karakter tomat populasi F2 dan F3 beserta nilai kemajuan seleksi dan heritabilitas arti sempitnya di bawah naungan pada musim 2

\begin{tabular}{|c|c|c|c|c|c|c|c|}
\hline \multirow{2}{*}{ Karakter } & \multicolumn{2}{|c|}{ Rata - Rata } & \multicolumn{2}{|c|}{ Kemajuan Seleksi } & \multirow{2}{*}{ Kategori } & \multirow{2}{*}{ Hns** $(\%)$} & \multirow{2}{*}{ Hns/Hbs* } \\
\hline & $\mathrm{F} 2$ & $\mathrm{~F} 3$ & Nilai & $(\%)$ & & & \\
\hline $\mathrm{TT}$ & 136.36 & 138.58 & 2.22 & 1.63 & Rendah & 31.94 & 0.37 \\
\hline INT & 4.43 & 4.39 & -0.05 & -1.06 & Rendah & -156.25 & -6.15 \\
\hline DBAT & 7.96 & 7.14 & -0.82 & -10.32 & Rendag & -317.76 & 27.2 \\
\hline PB & 3.16 & 3.09 & -0.07 & -2.13 & Rendah & -5.14 & -0.16 \\
\hline DB & 28.39 & 28.47 & 0.08 & 0.29 & Rendah & 7.74 & 0.13 \\
\hline $\mathrm{BB}$ & 16.14 & 15.72 & -0.42 & -2.61 & Rendah & -14.38 & -1.31 \\
\hline FS & 54.03 & 66.46 & 12.42 & 22.99 & Tinggi & 66.54 & 0.97 \\
\hline JBT & 41.84 & 50.47 & 8.63 & 20.62 & Tinggi & 25.77 & 0.37 \\
\hline BBT & 664.04 & 783.26 & 119.22 & 17.95 & Tinggi & 13.52 & 0.22 \\
\hline
\end{tabular}

Keterangan : $\quad$ TT $=$ Tinggi tanaman $(\mathrm{cm}), \mathrm{INT}=$ Panjang internode $(\mathrm{cm}), \mathrm{DBAT}=$ Diameter batang $(\mathrm{mm}), \mathrm{PB}=$ Panjang buah $(\mathrm{cm}), \mathrm{DB}=$ Diameter buah, BB = Bobot per buah, FS = Fruit set $(\%), \mathrm{JBT}=$ Jumlah buah per tanaman, BBT = Bobot buah per tanaman $(\mathrm{g})$, Hns $=$ Heritabilitas arti sempit, $*=$ Hbs mengacu pada Tabel $1, * *=$ jika bernilai negatif (-) maka dianggap nol (0)

Tabel 3. Nilai tengah dan ragam tinggi tanaman, panjang internode dan diameter batang segregan transgresif putatif tomat di bawah naungan dan pembandingnya

\begin{tabular}{lcccccc}
\hline \multirow{2}{*}{ Genotipe } & \multicolumn{2}{c}{ Tinggi tanaman $(\mathrm{cm})$} & \multicolumn{2}{c}{ Panjang internode $(\mathrm{cm})$} & \multicolumn{2}{c}{ Diameter batang $(\mathrm{cm})$} \\
\cline { 2 - 7 } & Rata-rata & Ragam & Rata-rata & Ragam & Rata-rata & Ragam \\
\hline P1 & 152.93 & 10.25 & 5.07 & 0.16 & 7.68 & 0.37 \\
P2 & 74.43 & 230.94 & 4.43 & 0.05 & 5.26 & 0.08 \\
TORA & 110.13 & 215.71 & 4.98 & 0.43 & 5.4 & 1.09 \\
F2 & 136.36 & 493.65 & 4.43 & 0.44 & 7.96 & 4.72 \\
F3 & 138.58 & 422.3 & 4.39 & 0.03 & 9.14 & 2.02 \\
\hline G40 & 110.28 & 83.71 & 4.37 & 0.07 & 4.58 & 0.90 \\
G384 & 138.5 & 773.29 & 4.44 & 0.41 & 7.44 & 1.02 \\
G326 & 123.44 & 439.8 & 4.63 & 0.30 & 5.28 & 0.96 \\
G80 & 134.22 & 357.87 & 4.20 & 0.46 & 5.47 & 1.90 \\
G345 & 134.78 & 223.52 & 4.40 & 0.13 & 4.81 & 0.22 \\
G374 & 134.08 & 236.17 & 4.53 & 0.17 & 6.34 & 0.93 \\
G373 & 156.66 & 288.23 & 4.30 & 0.09 & 6.60 & 1.47 \\
G380 & 146.97 & 751.32 & 4.53 & 0.84 & 5.00 & 0.21 \\
G363 & 152.63 & 455.43 & 4.53 & 0.07 & 6.26 & 0.24 \\
G370 & 134.5 & 808.71 & 4.08 & 0.25 & 4.94 & 1.15 \\
G367 & 151.58 & 188.53 & 4.08 & 0.29 & 5.45 & 1.18 \\
G381 & 131.6 & 44.13 & 4.43 & 0.12 & 4.84 & 0.16 \\
G208 & 152.27 & 493.65 & 4.50 & 0.44 & 4.32 & 1.07 \\
\hline
\end{tabular}


Karakter jumlah dan bobot buah per tanaman memiliki persentase kemajuan seleksi yang jauh lebih rendah dibandingkan persentase respon seleksinya, sementara karakter fruit set memiliki persentase kemajan seleksi yang lebih tinggi dibandingkan respon seleksinya. Hal ini mengindikasikan bahwa karakter jumlah dan bobot buah per tanaman lebih banyak dipengaruhi oleh gen-gen non aditif sedangkan karakter fruit set lebih banyak dikendalikan oleh gen-gen aditif. Hal ini dibuktikan dengan nilai rasio Hns/ Hbs karakter jumlah dan bobot buah per tanaman tomat yang $<0.5$ sementara nilai rasio $\mathrm{Hns} / \mathrm{Hbs}$ pada fruit set yang $0.5>$ dan hampir mendekati satu. Yunandra et al. (2016) memaparkan bahwa kemajuan seleksi yang baik pada tanaman tanaman cabai jika dilakukan pada karakter dengan nilai heritabilitas arti sempit yang tinggi atau pada karakterkarakter yang lebih banyak dikendalikan oleh gen aditif.

\section{Verifikasi Segregan Transgresif}

Hasil pengamatan menunjukkan bahwa tidak terdapat segregan transgresif berdasarkan karakter tinggi tanaman, panjang internode, diameter batang, panjang buah, diameter buah dan bobot per buah tomat pada kondisi naungan (Tabel 3 dan 4). Namun demikian, terdapat 5-7 segregan yang memiliki nilai ragam yang lebih kecil atau mendekati ragam tetua pada karakter tinggi tanaman, panjang internode, diameter batang dan panjang buah tomat. Hal ini diduga karena rendahnya keragaman genetik pada karakterkarakter tersebut pada populasi yang digunakan. Selain itu juga karena rendahnya pengaruh langsung dari karakterkarakter tersebut terhadap karakter bobot buah per tanaman (sebagai karakter seleksi) pada kondisi naungan (Ritonga et al., 2017)

Segregan transgresif berhasil diperoleh berdasarkan karakter fruit set, jumlah buah dan bobot buah per tanaman. Sebanyak $76 \%$ segregan terverifikasi sebagai segregan transgresif berdasarkan karakter fruit set, sedangkan berdasarkan karakter jumlah buah atau bobot buah pertanaman terdapat $23 \%$ segregan yang terverifikasi sebagai segregan transgresif (Tabel 5). Nurhidayah et al., (2017) melaporkan bahwa berdasarkan seleksi dengan karakter seleksi jumlah polong total, hanya dihasilkan $27 \%$ segregan transgresif dari 22 segregan yang diuji. Nurhidayah et al., (2017) juga melaporkan bahwa karakter hasil pada tanaman kacang tanah dikendalikan oleh banyak gen dan dikendalikan oleh aksi gen dominan.Hal ini menguatkan indikasi bahwa karakter hasil jumlah buah dan bobot buah per tanaman tomat lebih banyak dipengaruhi oleh gen-gen dominan pada kondisi naungan, sementara karakter fruit set lebih banyak dipengaruhi oleh gen-gen aditif.

Tabel 4. Rata-rata dan ragam bobot per buah, panjang buah dan diameter buah segregan transgresif putatif tomat di bawah naungan dan pembandingnya

\begin{tabular}{lcccccc}
\hline \multirow{2}{*}{ Genotipe } & \multicolumn{2}{c}{ BB } & \multicolumn{3}{c}{ PB } & DB \\
\cline { 2 - 7 } Pata-rata & Ragam & Rata-rata & Ragam & Rata-rata & Ragam \\
\hline P2 & 17.70 & 1.30 & 3.55 & 0.07 & 30.57 & 0.48 \\
TORA & 15.00 & 1.90 & 2.96 & 0.08 & 27.76 & 0.95 \\
F2 & 39.64 & 48.34 & 5.01 & 0.16 & 40.81 & 5.64 \\
F3 & 16.14 & 4.05 & 3.16 & 0.07 & 28.39 & 1.76 \\
\hline G40 & 15.72 & 7.06 & 3.09 & 0.11 & 28.47 & 4.35 \\
G384 & 14.81 & 5.51 & 2.72 & 0.05 & 29.87 & 2.87 \\
G326 & 16.47 & 11.18 & 3.35 & 0.20 & 29.64 & 8.97 \\
G80 & 20.37 & 44.66 & 3.62 & 0.28 & 29.75 & 7.11 \\
G345 & 12.20 & 2.62 & 2.58 & 0.01 & 27.66 & 1.60 \\
G374 & 17.62 & 6.11 & 3.28 & 0.10 & 31.07 & 14.16 \\
G373 & 13.42 & 9.45 & 2.98 & 0.06 & 23.50 & 3.10 \\
G380 & 15.49 & 15.85 & 2.83 & 0.07 & 29.58 & 5.59 \\
G363 & 20.82 & 50.51 & 3.62 & 0.27 & 25.41 & 61.84 \\
G370 & 15.12 & 7.58 & 3.31 & 0.08 & 28.27 & 3.97 \\
G367 & 14.85 & 12.73 & 3.2 & 0.09 & 29.37 & 4.98 \\
G381 & 15.22 & 14.67 & 2.92 & 0.08 & 29.81 & 7.78 \\
G208 & 15.82 & 7.62 & 2.94 & 0.13 & 29.02 & 4.27 \\
\hline
\end{tabular}


Tabel 5. Rata-rata dan ragam fruit set, jumlah buah per tanaman dan bobot buah per tanaman segregan transgresif putatif tomat di bawah naungan dan pembandingnya

\begin{tabular}{lcccccc}
\hline \multirow{2}{*}{ Genotipe } & \multicolumn{2}{c}{ Fruit set (\%) } & \multicolumn{2}{c}{ Jumlah buah per tanaman } & \multicolumn{2}{c}{ Bobot buah per tanaman $(\mathrm{g})$} \\
\cline { 3 - 7 } & Rata-rata & Ragam & Rata-rata & Ragam & Rata-rata & Ragam \\
\hline P1 & 52.86 & 222.58 & 44.33 & 42.33 & 784.70 & 11236.88 \\
P2 & 45.42 & 13.69 & 40.76 & 172.81 & 646.27 & 58306.92 \\
TORA & 58.10 & 266.27 & 18.36 & 13.45 & 722.57 & 25097.45 \\
F2 & 54.03 & 183.36 & 41.84 & 69.89 & 664.04 & 32934.27 \\
F3 & 66.46 & 179.62 & 50.47 & 184.73 & 783.26 & 34738.82 \\
\hline G40 & 74.85 & 317.30 & 37.43 & 79.33 & 557.56 & 29950.01 \\
G384 & 82.85 & 120.69 & 48.92 & 128.99 & 800.94 & 51372.25 \\
G326 & 70.32 & 179.45 & 41.18 & 300.76 & 774.65 & 52098.81 \\
G80 & 63.02 & 165.83 & 50.00 & 578.80 & 596.52 & 67058.98 \\
G345 & 95.24 & 187.93 & 47.62 & 329.33 & 858.13 & 38807.76 \\
G374 & 67.56 & 265.14 & 61.67 & 195.07 & 836.45 & 105090.12 \\
G373 & 56.56 & 36.84 & 59.14 & 286.48 & 946.49 & 197528.79 \\
G380 & 63.35 & 69.53 & 43.00 & 454.50 & 894.44 & 271542.40 \\
G363 & 48.50 & 99.47 & 35.67 & 187.47 & 540.48 & 47964.01 \\
G370 & 49.12 & 436.06 & 43.6 & 578.30 & 702.82 & 330969.08 \\
G367 & 56.30 & 69.47 & 37.00 & 64.80 & 579.84 & 62796.52 \\
G381 & 75.88 & 14.67 & 74.69 & 14.22 & 1183.57 & 56918.60 \\
G208 & 60.38 & 77.63 & 76.14 & 123.41 & 910.49 & 13747.24 \\
\hline
\end{tabular}

\section{KESIMPULAN}

Karakter fruit set menghasilkan nilai persentase respon seleksi dan kemajuan seleksi yang sama-sama tinggi, karakter jumlah buah dan bobot buah per tanaman tomat menghasilkan nilai persentase respon seleksi yang tinggi dan kemajuan seleksi yang rendah, sedangkan karakter vegetatif dan karakter buah tomat menghasilkan persentase respon yang sama-sama rendah pada kondisi naungan paranet 50\%. Segregan transgresif lebih banyak diperoleh berdasarkan karakter fruit set, lebih sedikit dihasilkan berdasarkan karakter jumlah dan bobot buah per tanaman serta dan tidak dihasilkan berdasarkan karakter vegetatif dan karakter buah. Hal ini mengindikasikan bahwa karakter fruit set lebih banyak dikendalikan gen-gen aditif, karakter jumlah buah dan bobot buah per tanaman tomat lebih banyak dikendalikan oleh gen-gen non aditif,dan tidak terdapat keragaman genetik pada karakter vegetatif dan karakter buah tomat pada kondisi naungan paranet 50\% pada populasi yang digunakan.

\section{DAFTAR PUSTAKA}

Baharuddin, R., M.A. Chozin, M. Syukur. Toleransi 20 genotipe tanaman tomat terhadap naungan. J. Agron. Indonesia 42(2):130-135.
Bahrun,A.H. 2012. Tanaman semusim penyusun agroforestri pada beberapa zona agroklimat di DAS Ciliwung Hulu, Disertasi, Program Pascasarjana, Institut Pertanian Bogor, Bogor.

Ferre, A.J.C., F.M. Agugliaro, M.D. Perez, A.C. Ortega, J.P. Alonzo. 2009. Effect of shading with aluminised screens on fruit production and quality in tomato (Solanum lycopesicum L.) under green house condition. Span J Agric Res. 7(1):41-49.

Hanson, P.M., J. Chen, G. Kuo., 2002. Gene action and heritability of high-temperature fruit set in tomato line CL5915. Hort Science 37(1):172-175.

Ilic, A.S., L. Milenkovic, L.Stanojevic, D.Cvetkovic, E. Fallik. 2012. Effect of the modification on light intensity by color shade nets on yield and quality of tomato fruits. Scientia Horticulturae 139:90-95.

Mulyani, A., D. Kuncoro, D. Nursyamsi, F. Agus. 2016. Analisis konversi lahan sawah: Penggunaan data spasial resolusi tinggi memperlihatkan laju konversi yang menghawatirkan. Jurnal Tanah dan Iklim 40(2):121-133. 
Nilawati, D.W. Ganefianti, D. Suryati. 2017. Variabilitas genetik dan heritabilitas pertumbuhan dan hasil 26 genotipe tomat. Akta Agrosia 20(1):25-34.

Nurhidayah, S., Y. Wahyu, W.B. Suwarno. 2017. Parameter genetik dan deteksi segregan transgresif pada populasi kacang tanah (Arachis hypogaea L.) generasi F3. J. Agron. Indonesia 45(2):162-168.

Ritonga, A.W., M. Syukur, M.A. Chozin, A. Maharijaya, Sobir. Genetic variability, heritability, correlation, and path analysis in tomato (Solanum lycopersicum) under shading condition. Biodiversitas 19(4):15271531 .

Rosyidah, N. N., Damanhuri, Respatijarti. 2016. Seleksi populasi F3 pada tanaman tomat (Lycopersicon esculentum Mill.). Jurnal Produksi Tanaman 4(3):231-239.

Sa'diyah, N., T.R. Basoeki, A.E. Putri, D. Maretha, S.D. Utomo. 2009. Korelasi, keragaman genetik, dan heritabilitas karakter agronomi kacang panjang populasi F3 keturunan persilangan testa hitam $\mathrm{x}$ lurik. J. Agrotropika 14:37-41.

Sulistyowati, D., M.A. Chozin, M. Syukur, M. Melati, D. Guntoro. 2016a. Selection of shade-tolerant tomato genotypes. Journal of Applied Horticulture 18(2):154-159.
Sulistyowati, D., M.A. Chozin, M. Syukur, M. Melati, D. Guntoro. 2016b. Karakter fotosintesis genotipe tomat senang naungan padaa intensitas cahaya rendah. J. Hort. 26(2):181-188.

Suwanda, M.H., M. Noor. 2014. Kebijakan pemanfaatan lahan rawa pasang surut untuk mendukung kedaulatan pangan nasional. Jurnal Sumberdaya Lahan 8:31-40.

Wassel-Beaver, L., J. W. Scott. 1992. Genetic heritability of fruit set, fruit weight and yield in tomato population grown in two high-temperature environments. J. Amer. Soc. Hort. Sci. 117(5):867-870.

Wulandari, J. E., I. Yulianah, D. Saptadi. 2016. Heritabilitas dan kemajuan genetik harapan empat populasi F2 tomat (Lycopersicumesculentum Mill.) pada budidaya organik. Jurnal Produksi Tanaman 4(5):361-369.

Yunandra, M. Syukur, A. Maharijaya. 2017. Seleksi dan kemajuan seleksi karakter komponen hasil pada persilangan cabai keriting dan cabai besar. J. Agron. Indonesia 45(2):169-174. 